\title{
Should I stay or should I go? The diurnal behaviour of plant-attached zooplankton in lakes with different water transparency
}

\author{
Satu ESTLANDER, ${ }^{*}$ Jukka HORPPILA, Mikko OLIN, Leena NURMINEN \\ Department of Environmental Sciences, University of Helsinki, P.O. Box 65, 00014 Helsinki, Finland \\ *Corresponding author: satu.estlander@helsinki.fi
}

\begin{abstract}
The role of transparency on the diurnal distribution of plant-attached cladocerans was studied in two similar-sized lakes with contrasting water colour. The diurnal attachment behaviour of Sida crystallina (O.F. Müller, 1776) was more pronounced in the less humic lake where the animals remained fixed on plants, indicating that staying attached was a more profitable option. In the highly humic lake, the pattern was opposite, and regardless of time the highest density observed was in the free-swimming individuals, with only few animals attached to the floating-leaves for refuge, indicating that low transparency provided sufficient protection against predation. The attached S. crystallina were larger compared to free-swimming individuals in the more transparent lake, suggesting greater vulnerability of large-sized individuals to predation. The results indicate that increasing concentrations of humic substances affecting the light environment may alter the diurnal behaviour and habitat use of plant-attached zooplankton.
\end{abstract}

Key words: Cladocera; humic lakes; littoral; Sida crystallina (O.F. Müller).

Received: August 2016. Accepted: November 2016.

\section{INTRODUCTION}

Many prey species resort to refuges to reduce their risk of predation, but usually this is a trade-off between predation risk and optimal feeding conditions (Lima and Dill, 1990; Lima, 1998; Gliwicz et al., 2006). In aquatic ecosystems with predators present, diel vertical migration (DVM) and diel horizontal migration (DHM) of zooplankton are examples of behavioural antipredator defences that are shaped by the trade-off between the favourable energy resources and level of safety (Lampert, 1993; Burks et al., 2002). It has been suggested that in aquatic ecosystems light is the proximate factor triggering the migration of zooplankton in predator presence (Lampert, 1993; Ringelberg, 1995). In DVM, decreasing light intensity triggers the upward movement of zooplankton during dusk (Lampert, 1993). Similarly, horizontal migration is generated by changes in light intensity (Burks et al., 2002), and according to Siebeck (1980) horizontal movement of zooplankton towards open water begins when a part of the optical window seen by the animal is darkened due to elevation of horizon. In lakes with high water colour, light attenuation is strong since dissolved humic substances efficiently absorb light, especially the short wavelengths (Kirk, 1994). Therefore, the concentration of humic substances in the water column affects the overall light intensity, spectral composition and the relative changes in the diurnal light climate (Kirk, 1994; Horppila et al., 2016), and thus inevitably influences the migratory behaviour displayed by zooplankton (Nurminen et al., 2007). The predation efficiency of planktivores is usually reduced in low water transparency, since most fish depend on vision in prey detection (Vinyard and O'Brien, 1976; Estlander et al., 2012). Additionally, predation is often size-selective and large-bodied zooplankton are more vulnerable (Brooks and Dodson, 1965).

In shallow lakes, littoral areas appear to play an important role in regulating horizontal migration of zooplankton (Lauridsen and Buenk, 1996; Moss et al., 1998). Large free-swimming zooplankton species tend to aggregate within the vegetation beds during daytime to seek refuge among macrophytes against fish predation (Lauridsen and Lodge, 1996; Burks et al., 2002). Compared to free-swimming zooplankton, cladocerans having the ability to attach on substrates may resort to different predator-avoidance strategies (Nurminen et al., 2010). In addition to diurnal migratory behaviour, they can also stay fixed to refuge substrata, such as macrophytes (Quade 1969; Nurminen et al., 2005). Floating-leaved vegetation, often dominating in low transparency waters, appears to harbour considerable densities of plant-attached cladocerans, such as Sida crystallina (O.F. Müller, 1776) (Moss et al., 1998). S. crystallina is a relatively large Cladoceran species and unlike most plant-associated zooplankton, $S$. crystallina has an anchoring organ (maxillary gland) (Günzl, 1978), which is used to attach to substrate, that secrete a gelatinous glue (Dodson et al., 2001). Nurminen et al. (2005) showed a dependency between the density of plant-attached cladocerans and turbidity, underlining 
the effect of visibility on the refuge effect of floatingleaved vegetation. The migratory behaviour of periodically plant-attached zooplankton species is poorly known (Moss et al., 1998; Nurminen et al., 2007), and the explanations for benefits of the attachment behaviour of $S$. crystallina are variable. Fairchild (1981) suggested that the attachment of $S$. crystallina is due of considerable energy saving for an organism which must otherwise swim continuously as it feeds. Nurminen et al. (2007) showed that attachment of S. crystallina may reduce susceptibility to fish predation, and light intensity is the proximate factor regulating the attachment of zooplankton.

To clarify the role of water transparency on the diurnal migration of plant-attached cladocerans we studied the diel attachment pattern of $S$. crystallina in two similar-sized lakes with different concentrations of humic substances and contrasting water colour. We followed the diurnal variation in the density of S. crystallina attached to floating-leaved yellow water lily Nuphar lutea (L.) Sm. and free-swimming in the water column. We also sampled for the differences in the diurnal variation in horizontal distribution of density of free-swimming S. crystallina among and attached to the vegetation. In both lakes, vision-using European perch (Perca fluviatilis L., 1758), very common in small humic lakes, is the main planktivore and the primary predator for S. crystallina (Estlander, 2011). Additionally, Estlander et al. (2010) showed that in less humic lakes, perch fed more on littoral zooplankton, such as S. crystallina, than in lakes with higher concentrations of humic substances. Therefore, we hypothesized that the diurnal attachment behaviour of S. crystallina is more pronounced in low water colour and higher transparency because of more intense predation threat due to increased visibility. Additionally, in high transparency we expected the amplitude of diurnal horizontal movement to be more pronounced and the large-sized individuals to be more prone to stay attached due to higher vulnerability to predation.

\section{METHODS}

The study was conducted in the Evo district $\left(61^{\circ} 13^{\prime} \mathrm{N}\right.$, $25^{\circ} 12^{\prime} \mathrm{N}$ ) in two small forest lakes, Iso Valkjärvi and Majajärvi, similar in morphometry (surface area 2.2 and 3.4 ha; mean depth 3.8 and $4.6 \mathrm{~m}$, respectively), and trophic status (total phosphorus 10 and $15 \mu \mathrm{gL}^{-1}$; total nitrogen 400 and $600 \mu \mathrm{gL}^{-1}$ ) but different in water colour (50 and $340 \mathrm{mg} \mathrm{Pt} \mathrm{L}^{-1}$ ) and Secchi depth (2.5 and $1 \mathrm{~m}$ ). Both lakes are inhabited by a perch population (Iso Valkjärvi 1360 ind ha ${ }^{-1}$, Majajärvi 2600 ind ha ${ }^{-1}$ ) (Horppila et al., 2010; Estlander, 2011). Based on long term gill net catches, in Majajärvi the densities of roach (Rutilus rutilus (L., 1758) (12 ind net $\left.{ }^{-1}\right)$ and perch (11 ind net $\left.{ }^{-1}\right)$ are on a similar level (Horppila et al., 2010). In Iso Valkjärvi the density of roach is very low $\left(0.2\right.$ ind net $\left.{ }^{-1}\right)$. Perch is known to be the

main predator for plant-attached S. crystallina (Estlander et al., 2010), whereas roach has been observed to consume $S$. crystallina to a much less extent (Nurminen et al., 2007). The macrophyte vegetation areas in both lakes are relatively narrow, because of the morphological features of the lakes. Macrophyte vegetation of both lakes consists mainly of floating leaved $N$. lutea stands and the density of submerged macrophytes is low ( $<5 \%$ of the vegetation zone) (Estlander, 2011).

To study the diurnal attachment of S. crystallina, water samples were taken on $17^{\text {th }}$ July at noon (12:00 hours), at midnight (24:00 hours) and next day, $18^{\text {th }}$ July at noon (12:00 hours). In both lakes, sampling was conducted with a tube sampler (volume $7.1 \mathrm{~L}$ ) from surface to bottom in three replicate transects from three zones: (A) among floating-leaved $N$. lutea stands, approximately $2 \mathrm{~m}$ from shore, (B) from the edge and (C) outside the stands (Fig. 1). The depths of sampling zones were: $\mathrm{A}=0.8( \pm 0.2) \mathrm{m}, \mathrm{B}=1.5( \pm$ $0.1) \mathrm{m}, \mathrm{C}=2( \pm 0.3) \mathrm{m}$. The three-replicate sampling transects within both lakes were separated by a 100-200 m distance. Thus, according to the swimming speed of $S$. crystallina (Johansson 1995), sampling transect were independent of each other. Three replicates samples were collected from each zone of each transect. Each replicate consisted of five tube sampler hauls that were assembled into one integrated sample, filtered through a $50-\mu \mathrm{m}$ net and preserved with formaldehyde. To determine the density of attached $S$. crystallina, three randomly selected $N$. lutea leaves were collected from each sampling transect. Each stem was cut below the water surface and the leaf was rapidly moved into a small container held near (Nurminen et al., 2007). In the laboratory, S. crystallina from both water

3-5 m

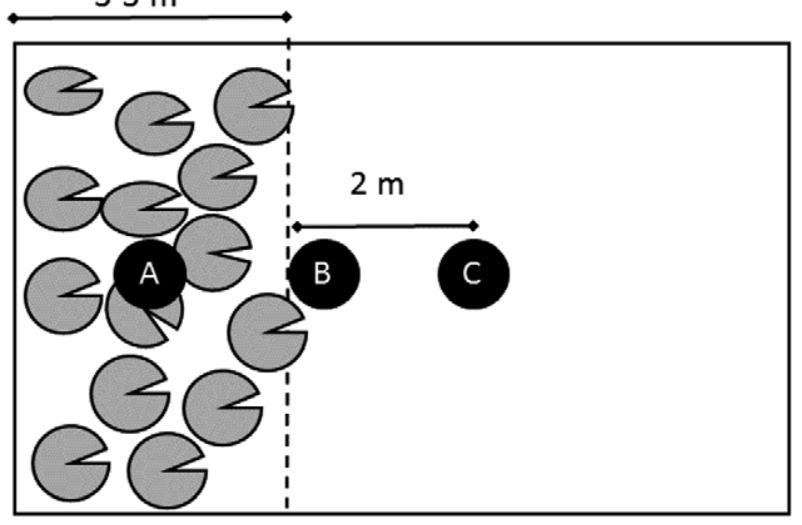

Fig. 1. Sketch of the sampling procedure. Sampling was conducted with tube sampler from surface to bottom in three different sites of lake and from each site, samples were taken from three zones: (A) among floating-leaved $N$. lutea stands, from the edge (B) and outside the stands (C). The depth of sampling zones in three sites per lake were on average: $A=0.8( \pm 0.2) \mathrm{m}$, $\mathrm{B}=1.5( \pm 0.1) \mathrm{m}, \mathrm{C}=2( \pm 0.3) \mathrm{m}$. 
column and leaf samples were enumerated and the length (from the anterior edge of the carapace to the posterior edge of the carapace) of 40 randomly selected individuals per each sample measured.

In both lakes, samples for chlorophyll- $a$ were taken each sampling time among the vegetation and outside the stands, and filtered through Whatman GF/C filters and analysed spectrophotometrically after extraction with ethanol. Temperature and dissolved oxygen concentration were measured with a YSI-6600 (YSI Inc., Yellow Springs, OH, USA) and light intensity with a LI-1400 datalogger with quantum sensors (LI-COR Biosciences, Lincoln, NE, USA). Light attenuation coefficient was calculated from light intensity measurement from the surface ( $1 \mathrm{~cm}$ below water level) and at $1 \mathrm{~m}$ depth. Light attenuation was calculated by the formula:

$I_{z}=I_{0} e^{-k z}$

where $I_{z}$ is light intensity at depth ${ }_{z}, I_{0}$ intensity below the water surface, $k$ attenuation coefficient, $z$ depth.

The density (\% coverage) of $N$. lutea was estimated using a $1 \mathrm{~m}^{2}$ frame (five replicates) from each sampling sites of lake and the surface area of the lake covered by the macrophytes was measured using GPS in the first day of sampling.

\section{Statistical analyses}

The coverage (\%) of $N$. lutea at each sampling transect and lake were compared with analysis of variance (ANOVA) (arcsin $\sqrt{x}$-transformed data). Differences in population densities and size-structure of S. crystallina between lakes were compared with analysis of variance for repeated measurements (ANOVAR). The diurnal variations in the density of $S$. crystallina (ind $\mathrm{m}^{-2}$ ) in the water column and attached to leaves in the two lakes were compared with ANOVAR. Additionally, the between-lake diurnal variations in the horizontal distribution of the free-swimming $S$. crystallina (ind $\mathrm{m}^{-2}$ ) were assessed using ANOVAR. Before the analyses, the datasets were checked for normality and $\ln (\mathrm{x}+1)$ - transformed if necessary. The paired sample $t$ test was used to compare within-lake differences in the length of attached and free-swimming $S$. crystallina. A logistic regression model was used to analyse whether the probability of $S$. crystallina attachment behaviour is dependent on length:

$$
y=\exp (\alpha+\beta L)[1+\exp (\alpha+\delta L T)]^{-1}
$$

where $y$ is the attachment of $S$. crystallina on the $N$. lutea leaf recorded as 0 (not attached) or 1 (attached). $L=S$. crystallina length, and $\alpha, \beta$, and $\delta$ are parameters. The statistical analyses were performed using SYSTAT ver. 15.0 (SPSS Inc.).

\section{RESULTS}

Temperature $\left(18^{\circ} \mathrm{C}\right.$ Iso Valkjärvi; $20^{\circ} \mathrm{C}$ Majajärvi), oxygen concentration ( 8 and $7 \mathrm{mg} \mathrm{L}^{-1}$, respectively) and chlorophyll $a$ (7 and $9 \mu \mathrm{g} \mathrm{L}^{-1}$ ), did not show significant differences between lakes, sampling sites or sampling times. The vertical light intensity profile varied considerably between the lakes, in Iso Valkjärvi at $1 \mathrm{~m}$ depth $15 \%$ of surface light was remaining, whereas in the highly humic Lake Majajärvi at corresponding depth only $2 \%$ prevailed, and the corresponding light attenuation coefficient values was $0.015 \mathrm{~cm}^{-1}$ in Iso Valkjärvi and $0.03 \mathrm{~cm}$ ${ }^{1}$ in Majajärvi. The coverage of macrophytes from the total lake area was higher in Iso Valkjärvi (25 \%) than in Majajärvi (12\%), but the coverage of $N$. lutea in each sampling transect (average $62 \%$ ) showed no significant variation within or between lakes $(\mathrm{P}>0.05)$.

There was a significant interaction between time of day, water colour and attachment of $S$. crystallina (ANOVAR: time $\mathrm{x}$ water colour $\mathrm{x}$ attachment: $F_{2,19}=5.51$, $\mathrm{P}=0.013$ ) (Tab. 1; Fig. 2). Regardless of time, in less

Tab. 1. Results from repeated analysis of variance: $S$. crystallina density=time (three levels) $\mathrm{x}$ water colour (two levels) $\times$ attachment (two levels).

\begin{tabular}{|c|c|c|c|c|c|}
\hline Source & DF & SS & MS & $\mathbf{F}$ & $\mathbf{P}$ \\
\hline Water colour & 1 & 26.95 & 26.95 & 36.42 & $<0.001 *$ \\
\hline Replicates (water colour) & 4 & 1.08 & 0.27 & 0.36 & 0.831 \\
\hline Time & 2 & 0.77 & 0.39 & 0.52 & 0.602 \\
\hline Attachment & 1 & 5.04 & 5.04 & 6.81 & $0.017 *$ \\
\hline Water colour*time & 2 & 1.91 & 0.95 & 1.29 & 0.299 \\
\hline Water colour*attachment & 1 & 83.37 & 83.37 & 112.68 & $<0.001 *$ \\
\hline Time*attachment & 2 & 0.72 & 0.36 & 0.49 & 0.622 \\
\hline Water colour*time*attachment & 2 & 8.15 & 4.08 & 5.51 & $0.013 *$ \\
\hline Error & 19 & & & & \\
\hline
\end{tabular}

* Significant at $P<0.05$. 
humic Iso Valkjärvi the density of attached $S$. crystallina (all data pooled) was higher $\left(9600 \pm 1450 \mathrm{SE}\right.$ ind $\left.\mathrm{m}^{-2}\right)$ compared to free-swimming density $(1100 \pm 240 \mathrm{SE}$ ind $\mathrm{m}^{-2}$ ). In Majajärvi, the opposite phenomenon was observed the majority of individuals being free-swimming $\left(4900 \pm 1400 \mathrm{SE}^{2}\right.$ ind $\left.\mathrm{m}^{-2}\right)$ and with a very low density of plant-attached individuals $\left(80 \pm 20 \mathrm{SE}\right.$ ind $\left.\mathrm{m}^{-2}\right)$ (Tab. 1 ; Fig. 2). There was a decrease in attached and an increase in free-swimming S. crystallina from day to night in Iso Valkjärvi, whereas no clear trend in free-swimming individuals was observed in Majajärvi (Fig. 2). Time or attachment alone were not significant (ANOVAR: $\mathrm{P}>0.05$ ), thus suggesting that the overall population densities were constant within both lakes during the whole study period. However, the overall density of S. crystallina population was higher in Iso Valkjärvi than in Majajärvi (Tab. 1). The density of free-swimming $S$. crystallina increased during the night time in both lakes (ANOVAR time: $F_{4,24}=5.79$, $\mathrm{P}<0.01$; Fig. 3). In Majajärvi, the average density of freeswimming individuals was higher among vegetation than in the other zones (Fig. 3), but in Iso Valkjärvi no differences between zones were observed (ANOVAR: water colour $\mathrm{x}$ habitat: $F_{4,24}=1.01, \mathrm{P}=0.42$ ). The interaction term time $\mathrm{x}$ habitat $\mathrm{x}$ water colour was not significant (ANOVAR: $\mathrm{P}>0.05$ ), suggesting that the diurnal behaviour of free-swimming $S$. crystallina was similar in both lakes (Fig. 3). The average length $(940 \pm 20 \mathrm{SE} \mu \mathrm{m})$ of $S$. crystallina did not vary between lakes (ANOVAR: $\mathrm{P}>0.05$ ). However, the attached S. crystallina individuals were larger than free-swimming individuals ( $t$-test: $\mathrm{P}=0.01)$ in Iso Valkjärvi. In highly humic Majajärvi, no size difference was detected between attached and freeswimming individuals $(t$-test: $\mathrm{P}>0.05)$. However, the probability of $S$. crystallina to attach to $N$. lutea leaves was dependent on $S$. crystallina length (logistic regression analysis: $\mathrm{P}<0.001$ ) as larger individuals had a greater tendency to be attached in both lakes. In addition, the probability of attachment of small and average-sized $(400-1200 \mu \mathrm{m}) S$. crystallina was higher in low water colour than in high water colour (Fig. 4).

\section{DISCUSSION}

Corroborating our hypothesis, the attachment behaviour of S. crystallina was more pronounced in the less humic Iso Valkjärvi, where the animals showed a distinct pattern by mostly remaining fixed on plants regardless of time, indicating that staying attached to vegetation was a more profitable option. When habitats plenty with resources are most dangerous due to predation, $S$. crystallina must choose between food acquisition and mortality risk (Lima and Dill, 1990). The majority of the S. crystallina in Iso Valkjärvi were attached to plants due to the high predation risk, but a nocturnal decrease in attached animals and increase in free-swimming animals was observed, indicating diurnal habitat change from the sheltering vegetation to feeding in the water column at night.

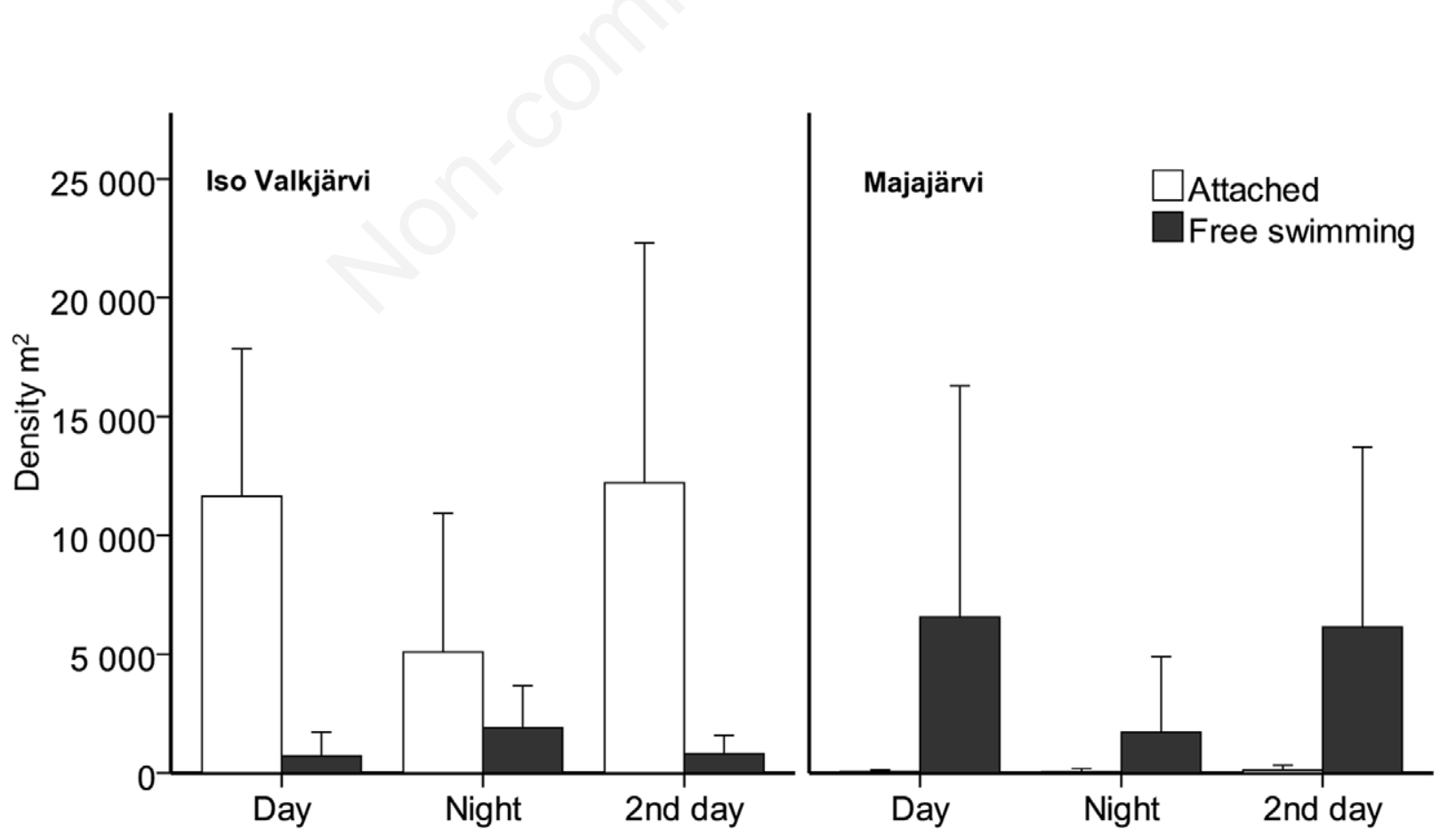

Fig. 2. Diurnal variation of Sida crystallina density (ind $\mathrm{m}^{-2}$ ) attached (white bars) and free-swimming (black bars) in Iso Valkjärvi (50 $\left.\mathrm{mg} \mathrm{Pt} \mathrm{L}{ }^{-1}\right)$ and Majajärvi (340 $\left.\mathrm{mg} \mathrm{Pt} \mathrm{L}^{-1}\right)( \pm 95 \%$ confidence limits). 
The pattern was the opposite in the highly humic Majajärvi. The study included only one diurnal cycle, but numerous aspects confirmed that the between-lake difference in the behaviour of S. crystallina was due to the difference in water quality and the diurnal behaviour of cladocerans is rather persistent (Haney and Donald, 1975). In Majajärvi, the highest density was always observed in the free-swimming individuals among vegetation, with only few animals attached to the floating-leaves for refuge. Apparently, low transparency due to high water colour together with the shadow of the floating leaves provided enough protection against predation and thus, $S$. crystallina could remain free-swimming. The animal prefers suspension feeding (Downing, 1981) which is more efficient in the swimming mode moving in the water column than in a sessile mode while attached. In contrast to Fairchild (1981) but in line with Nurminen et al. (2007, 2010) the distinct diurnal variation in S. crystallina attachment behaviour in contrasting water colour underlines the proximate role of light.

Both resources and predation interact and can have effects on herbivorous zooplankton (Nicolle et al., 2011). However, in humic lakes interspecific competition for food among zooplankton is usually less important in determining the zooplankton community than predation (Masson and Pinel-Alloul 1998). For example, the heterotrophic flagellates can play an important role as a food resource for zooplankton especially in humic lakes (Salonen and Hammar, 1986). Therefore, the available food resources potentially differed between studied lakes, since they differed distinctly in water colour. However, Geller and Müller (1981) suggested that S. crystallina is unable to feed on suspended bacterial cells due to their coarse filter meshes. Here, the chlorophyll $a$ concentration did not show diurnal, spatial or between-lake variation, but predation pressure most likely varied between lakes. Fish density in the highly humic Majajärvi was considerably higher compared to the less humic Iso Valkjärvi, indicating that the prevailing free-swimming mode in high water colour was not due to lack of predation pressure. On the contrary, S. crystallina remained free-swimming despite the higher predation pressure, which is in line with Estlander et al. (2009), who showed that the importance of the littoral zone as a refuge for zooplankton decreases with decreasing transparency. The darker water colour the less fish tend to feed on littoral zooplankton species or macrophyte-associated benthic macroinvertebrates (Estlander et al., 2010).

In Iso Valkjärvi, the nocturnal densities of free-swimming S. crystallina were overall higher than those observed in daytime, indicating that in clear water swimming in the water column was safer in the darkness. In contrast, in the highly humic Majajärvi there was a density peak underneath the floating leaves, supporting the assumption that low transparency and shadow of the leaves together provided sufficient shelter for the animals to remain free-swimming at daylight (Nurminen et al., 2007). Planktivores can most efficiently detect zooplank-

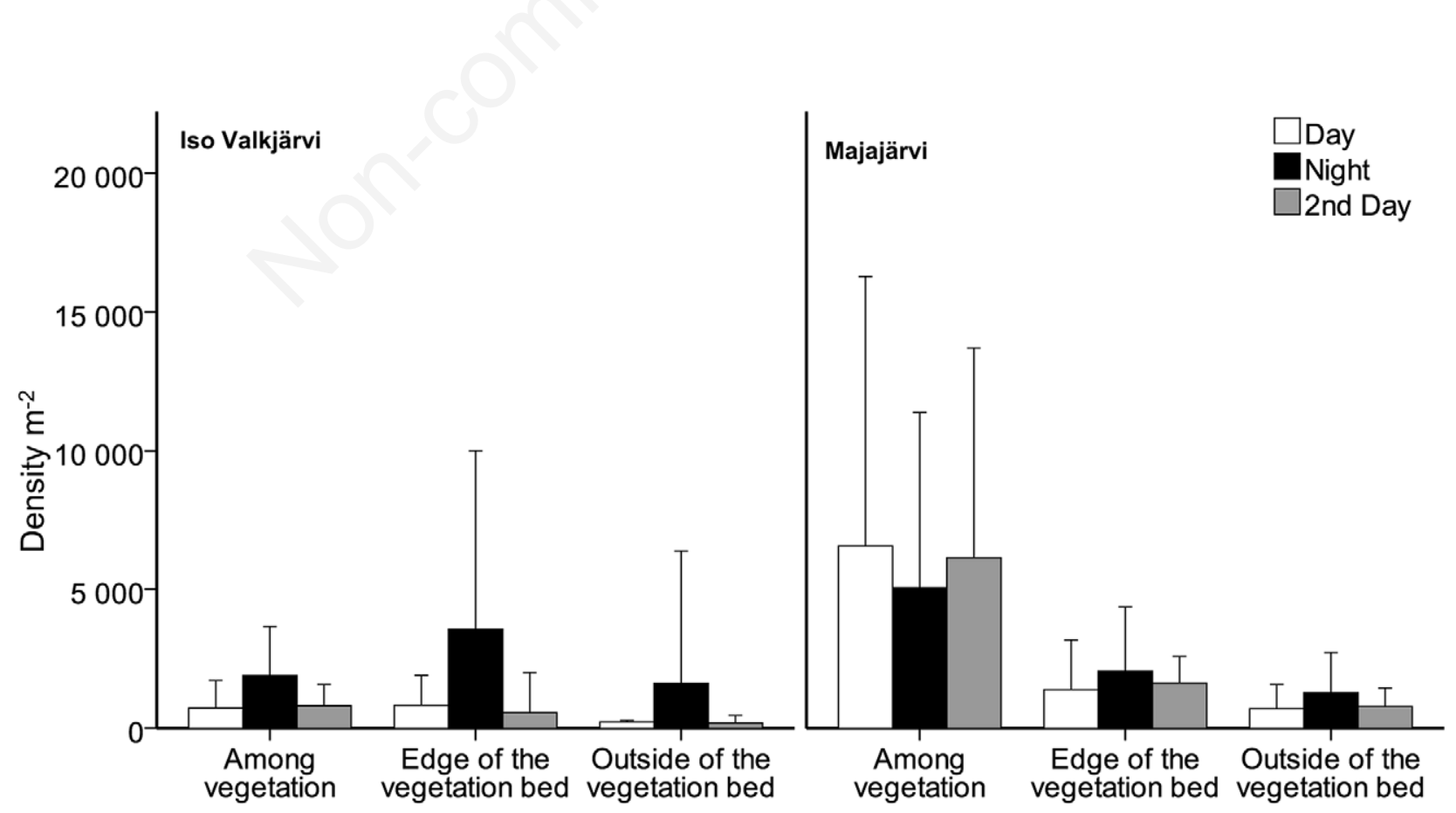

Fig. 3. Horizontal distribution of free-swimming Sida crystallina density (ind $\mathrm{m}^{-2}$ ) during day (white and grey bars) and night (black bars) in Iso Valkjärvi (50 mg Pt L ${ }^{-1}$ ) and Majajärvi (340 $\left.\mathrm{mg} \mathrm{Pt} \mathrm{L}^{-1}\right)( \pm 95 \%$ confidence limits). 
ton individuals outside Snell's window or the boundary of the window (at an angle $\geq 48.6^{\circ}$ ), where light has been reflected from the surface and comes from the water underneath the fish (Janssen, 1981). The floating leaf covers the window, and a predator outside the leaf has a raised contrast perception threshold, making it difficult to detect a shaded target (Helfman, 1981). Therefore, predation risk in the shade of the floating leaf is lower than in the open water under the same light environment. The leaf cover also affects the spectral composition of light because the floating leaves absorb short wavelength light whereas long wavelengths penetrate the leaves more efficiently (Nurminen and Horppila 2006). In high water colour, together with the overall shading effect decreasing visibility, the spectral composition underneath the leaves may not be optimal for visual predation, because for example perch has low sensitivity for wavelengths $>700 \mathrm{~nm}$ (Cameron 1982) dominating under the leaf (Nurminen and Horppila, 2006). In addition, the prevailing sidewelling light under the leaf cover hampers prey detection by fish (Lythgoe, 1980).

When comparing the free-swimming and plant-attached modes of S. crystallina, their difference in vulnerability to predation is imminent. When fish prey on attached individuals, instead of a three-dimensional visual field they face a flat two-dimensional visual field where the prey is harder to detect (Ware, 1973; Nurminen et al., 2010). Fairchild (1982) reported largemouth bass (Micropterus salmoides Lacepède, 1802) to make the choice to attack from $1 \mathrm{~cm}$ distance while predating on attached S. crystallina, and Nurminen and Horppila (2006) found decreasing visibility to shorten the attack distance of perch predating on S. crystallina attached to N. lutea. Additionally, prey that are stationary and attached to a surface are

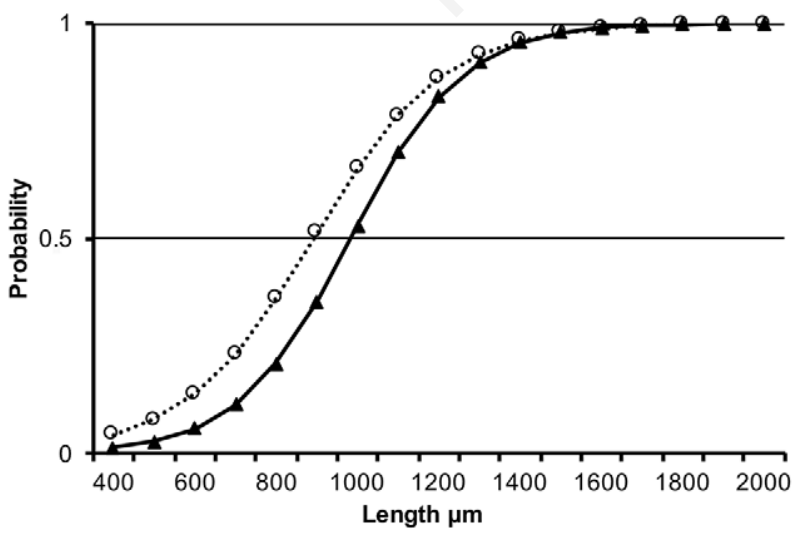

Fig. 4. Probability of attachment of Sida crystallina to Nuphar lutea leaves against Sida crystallina length estimated with logistic regressions in low (50 $\mathrm{mg} \mathrm{Pt} \mathrm{L}^{-1}$ ) (dotted line) and high (340 mg Pt L ${ }^{-1}$ ) (solid line) water colour. generally less prone to detection by predators than freely moving objects (Ware, 1973).

Fairchild (1981) suggested that larger S. crystallina had a greater tendency to remain in attached position than smaller individuals due to higher energy loss while swimming. Accordingly, in our study the attached S. crystallina individuals were larger, but only in the less humic Iso Valkjärvi. This indicates that in good visibility larger individuals are more vulnerable to predation and choose to stay attached, since vision-using fish, such as perch, select positively for the large-sized cladocerans (Estlander et al., 2010), and transparency is shown to affect size-selectivity of planktivores (Vinyard and O'Brien, 1976). In addition, large female cladocerans that carry eggs are more visible, and thus easy targets for fish (Gliwicz and Pijanowska, 1989). Our results are also in line with the finding that juvenile Sida swim better and more frequently than adults (Fairchild, 1981). The causal relationship between size and attachment may be ambiguous, since the dominance of smaller free-swimming S. crystallina over attached individuals in less humic Iso Valkjärvi may also be due to size-selective fish predation or the tendency of small-sized individuals to show less antipredatory responses, such as attachment. However, the logistic regression showed that water colour affects the length at which S. crystallina individuals prefer the attached mode. In high transparency, the individuals attach to the floating leaved surface at a smaller size than in low transparency.

\section{CONCLUSIONS}

In aquatic ecosystems, the level of safety for zooplankton is usually linked to the vertical or horizontal dimension of the habitat (Werner and Gilliam, 1984; Clark and Levy, 1988), but also the prevailing light environment is important, because prey capture of planktivorous fish is mainly based on vision (Vinyard and O'Brien, 1976; Taylor, 1980). During the last decades, lakes in Northern and Central Europe have undergone an increase in dissolved organic carbon concentrations, resulting in decreasing visibility and brownification of waters (Vuorenmaa et al., 2006). Our study suggests that increasing concentrations of humic substances that affect the light environment underwater may alter the diurnal behaviour and habitat use of plant-attached zooplankton in lakes with predation pressure.

\section{ACKNOWLEDGMENTS}

We thank Mika Vinni for helping in the field. The study was financially supported by the Bergsrådet Bror Serlachius Foundation. 


\section{REFERENCES}

Brooks JL, Dodson SI, 1965. Predation, body size and composition of plankton. Science 150:28-35.

Burks RL, Lodge DM, Jeppesen E, Lauridsen TL, 2002. Diel horizontal migration of zooplankton: costs and benefits of inhabiting the littoral. Freshwater Biol. 47:343-365.

Cameron DE, 1982. The photopic spectral sensitivity of a dichromatic teleost fish (Perca fluviatilis). Vision Res. 22:1341-1348.

Clark CW, Levy DA, 1988. Diel vertical migrations by juvenile sockeye salmon and the antipredation window. Am. Nat. 131:271-290.

Dodson SL, Caceres CE, Rogers DC, 2001. Cladocera and other Branchiopoda, p. 850-872. In: J.H. Thorp and A.P. Covich (eds.), Ecology and classification of North American freshwater invertebrates. Academic Press, San Diego.

Downing JA,1981. In situ foraging responses of three species of littoral cladocerans. Ecol. Mon. 51:85-103.

Estlander S, 2011. Fishes of the darkness. Water colour-regulated competitive interactions in the humic lakes. Ph.D. Thesis, University of Helsinki.

Estlander S, Horppila J, Olin M, Vinni M, Lehtonen H, Rask M, Nurminen L, 2012. Troubled by the humics - effects of water colour and interspecific competition on the feeding efficiency of planktivorous perch. Boreal Environ. Res. 17:305-312.

Estlander S, Nurminen L, Olin M, Vinni M, Horppila J, 2009. Seasonal fluctuations in macrophyte cover and water transparency of four brown-water lakes - implications for crustacean zooplankton in littoral and pelagic habitats. Hydrobiologia 620:109-120.

Estlander S, Nurminen L, Olin M, Vinni M, Immonen S, Rask M, Ruuhijärvi J, Horppila J, Lehtonen H, 2010. Diet shifts and food selection of perch (Perca fluviatilis) and roach (Rutilus rutilus) in humic lakes of varying water colour. J. Fish Biol. 77:241-256.

Fairchild GW, 1981. Movement and microdistribution of Sida crystallina and other littoral microcrustacea. Ecology 62:1341-1352.

Fairchild GW, 1982. Population responses of plant-associated invertebrates to foraging by largemouth bass fry (Micropterus salmoides). Hydrobiologia 96:169-176.

Geller W. Müller H. 1981. The filtration apparatus of Cladocera: filter mesh-sizes and their implications on food selectivity. Oecologia 49:316-321.

Gliwicz MZ, Slon J, Szynkarczyk I, 2006. Trading safety for food: evidence from gut contents in roach and bleak captured at different distances offshore from their daytime littoral refuge. Freshwater Biol. 51:823-839.

Haney JF, Hall DJ, 1975. Diel vertical migration and filter-feeding activities of Daphnia. Arch. Hydrobiol. 75:413-441.

Helfman GS, 1981. The advantage to fishes of hovering in shade. Copeia 1981:392-400.

Horppila J, Olin M, Vinni M, Estlander S, Nurminen L, Rask M, Ruuhijärvi J, Lehtonen H, 2010. Perch production in forest lakes: the contribution of abiotic and biotic factors. Ecol. Freshwater Fish 19:257-266.

Janssen J, 1981. Searching for zooplankton just outside Snell`s window. Limnol. Oceanogr. 26:1168-1171.
Johansson F, 1995. Increased prey vulnerability as a result of prey-prey interactions. Hydrobiologia 308:131-137.

Kirk JTO,1994. Light and photosynthesis in aquatic ecosystems. Cambridge University Press, Cambridge: 509 pp.

Lampert W, 1993. Ultimate causes of diel vertical migration of zooplankton: new evidence for the predator-avoidance hypothesis. Ergebn. Limnol. 39:79-88.

Lauridsen TL, Buenk I, 1996. Diel changes in the horizontal distribution of zooplankton in the littoral zone of two shallow eutrophic lakes. Arch. Hydrobiol.137:167-176.

Lauridsen TL, lodge dm, 1996. avoidance by daphnia magna of fish and macrophytes: chemical cues and predator-mediated use of macrophyte habitat. Limnol. Oceanogr. 41:794-798.

Lima SL, 1998. Nonlethal effects in the ecology of predatorprey interactions. What are the ecological effects of antipredator decision-making? Bioscience 48:25-34.

Lima SL, Dill LM, 1990. Behavioral decisions made under the risk of predation:a review and prospectus. Can. J. Zool. 68:619-640.

Lythgoe JN, 1980. Vision of fishes: ecological adaptations. In A. Ali (ed.), Environmental physiology of fishes. Plenum Press, New York: 431-466 pp.

Masson S, Pinel-Alloul B, 1998. Spatial distribution of zooplankton biomass size fractions in a bog lake: abiotic and (or) biotic regulation? Can. J. Zool. 76:805-823.

Moss B, Kornijów R, Measey GJ, 1998. The effects of nymphaeid (Nuphar lutea) density and predation by perch (Perca fluviatilis) on the zooplankton communities in a shallow lake. Freshwater Biol. 39:689-697.

Nicolle A, Hansson LA, Brodersen J, Nilsson PA, Brönmark C, 2011. Interactions between predation and resources shape zooplankton population dynamics. PloS One 6:e16534.

Nurminen L, Horppila J, 2006. Efficiency of fish feeding on plant-attached prey -effect of inorganic turbidity and plantmediated changes in the light environment. Limnol. Oceanogr. 51:1550-1555.

Nurminen L, Horppila J, Hagman AM, Niemistö J, PekcanHekim Z, 2005. Synthesis on the role of macrophytes in a clay-turbid lake - structuring and stabilizing functions affecting water quality. Arch. Hydrobiol. Spec. Iss. Adv. Limnol. 59:105-123.

Nurminen L, Horppila J, Pekcan-Hekim Z, 2007. Effect of light and predator abundance on the habitat choice of plant-attached zooplankton. Freshwater Biol. 52:539-548.

Nurminen L, Pekcan-Hekim Z, Repka S, Horppila J, 2010. Effect of prey type and inorganic turbidity on littoral predatorprey interactions in a shallow lake:an experimental approach. Hydrobiologia 646:209-214.

Quade HW, 1969. Cladoceran faunas associated with aquatic macrophytes in some lakes in northwestern Minnesota. Ecology 170-179.

Ringelberg J, 1995. Changes in light intensity and diel vertical migration: a comparison of marine and freshwater environments. J. Mar. Biol. Ass. UK 75:15-25.

Salonen K, Hammar T, 1986. On the importance of dissolved organic matter in the nutrition of zooplankton in some lake waters. Oecologia 68:246-253.

Siebeck OH, 1980. Optical orientation of pelagic crustaceans and its consequences in the pelagic and littoral zones, p. 2838. In: W.C. Kerfoot (ed.), Evolution and ecology of zoo- 
plankton communities. University Press of New England. Soranno PA, Carpenter SR, He X, 1993. Zooplankton biomass and body size, p. 172-188. In: S.R. Carpenter and J.F. Kitchell (eds.), The trophic cascade in lakes. Cambridge University Press, Cambridge.

Taylor BE, 1980. Size-selective predation on zooplankton, p. 377-387. In: W.C. Kerfoot (ed.), Evolution and ecology of zooplankton communities. University Press of New England.

Vinyard GL, O’Brien WJ, 1976. Effects of light and turbidity on the reaction distance of Bluegill (Lepomis macrochirus). J. Fish. Res. Board Can. 33:2845-2849.

Vuorenmaa J, Forsius M, Mannio J, 2006. Increasing trends of total organic carbon concentrations in small forest lakes in Finland from 1987 to 2003. Sci. Tot. Environ. 365:47-65.

Ware DM, 1973. Risk of epibenhtic prey to predation by rainbow trout (Salmo gairdneri). J. Fish. Res. Board Can. 30:787-797.

Werner EE, Gilliam JF, 1984. The ontogenetic niche and species interactions in size structured populations. Ann. Rev. Ecol. System. 15:393-425. 